\title{
Cellular cholesterol efflux to plasma from moderately hypercholesterolaemic type 1 diabetic patients is enhanced, and is unaffected by simvastatin treatment
}

Received: 23 December 2004 / Accepted: 7 February 2005 / Published online: 5 May 2005

(C) Springer-Verlag 2005

\begin{abstract}
Aim/hypothesis: Cellular cholesterol efflux to plasma is important in reverse cholesterol transport and may be affected by simvastatin in type 1 diabetes mellitus. Methods: In 14 moderately hypercholesterolaemic type 1 diabetic and 13 healthy men we determined plasma (apo) lipoproteins, pre- $\beta$ HDL formation, cholesteryl ester transfer protein (CETP) activity, phospholipid transfer protein (PLTP) activity, cholesterol esterification, cholesteryl ester transfer and the capacity of plasma to induce cholesterol efflux out of Fu5AH cells and fibroblasts. After diet runin, diabetic patients were randomly treated with simvastatin 10,20, $40 \mathrm{mg}$ and placebo, once daily each, for 6 weeks in a double-blind crossover design. Results: Plasma very low density lipid protein (VLDL)+LDL cholesterol, LDL cholesterol, HDL phospholipids, apolipoprotein (apo) A-I, apo B, CETP activity, PLTP activity, cholesterol esterification, cholesteryl ester transfer and the capacity of plasma to induce cholesterol efflux from Fu5AH cells and fibroblasts were higher in diabetic patients. Pre- $\beta$ HDL formation was unaltered. Simvastatin treatment decreased VLDL+LDL cholesterol, LDL cholesterol, triglycerides and apo B, CETP activity, cholesterol esterification and cholesteryl ester transfer. HDL cholesterol increased and its change was correlated with the change in cholesteryl ester transfer. The ability to promote cholesterol efflux from
\end{abstract}

R. de Vries $(\bowtie) \cdot$ M. N. Kerstens · W. J. Sluiter · A. van Tol ·

R. P. F. Dullaart

Department of Endocrinology, University of Groningen and

University Medical Center Groningen,

P.O. Box 30.001 Groningen, 9700, The Netherlands

e-mail: r.de.vries@int.umcg.nl

Tel.: +31-50-3611977

Fax: $+31-50-3619392$

\section{A. K. Groen}

Department of Experimental Hepatology,

Academic Medical Center,

Amsterdam, The Netherlands

A. van Tol

Department of Cell Biology and Genetics,

Erasmus University Medical Center,

Rotterdam, The Netherlands
Fu5AH cells and fibroblasts did not change after simvastatin. Conclusions/interpretation: The capacity of plasma from moderately hypercholesterolaemic type 1 diabetic patients to induce cholesterol efflux out of Fu5AH cells and fibroblasts is enhanced, probably due to higher apo A-I, HDL phospholipids and PLTP activity. Simvastatin increases HDL cholesterol in type 1 diabetic patients via lowering of plasma cholesteryl ester transfer. The HDL changes after simvastatin do not increase cellular cholesterol efflux further.

Keywords Cellular cholesterol efflux · High density lipoprotein · Lipid transfer - Simvastatin ·

Type 1 diabetes mellitus

Abbreviations ABCA1: ATP-binding cassette transporter A1 - ABCG1: ATP-binding cassette transporter G1 . ABCG4: ATP-binding cassette transporter G4 - Apo: apolipoprotein - BCA: bicinchoninic acid - CETP: cholesteryl ester transfer protein - CLA-1: CD36 and LIMPII analogous-1 receptor - HMG Co-A reductase: hydroxymethylglutaryl Co-A reductase - LCAT: lecithin: cholesterol acyl transferase - PLTP: phospholipid transfer protein - RCT: reverse cholesterol transport - SR-BI: scavenger receptor class B type I .

VLDL: very low density lipoprotein

\section{Introduction}

The reverse cholesterol transport (RCT) pathway, whereby cholesterol is transported from peripheral tissues back to the liver for metabolism and excretion in the bile, is important for atherosclerosis protection $[1,2]$. The RCT system consists of several steps beginning with the uptake of cholesterol from peripheral cells to extracellular acceptors including lipid-poor apolipoprotein (apo) A-I and pre- $\beta$ HDL particles [2-7]. This process is followed by cholesterol esterification via lecithin:cholesterol acyl transferase (LCAT) and the generation of mature, spherical HDL. Subsequently, cholesteryl ester transfer protein 
(CETP) catalyses the transfer of cholesteryl esters from HDL to apo B-containing lipoproteins. HDL-derived cholesteryl esters can be taken up directly by the liver, as well as indirectly via CETP-mediated transfer to apo B-containing lipoproteins [8]. Human plasma also contains phospholipid transfer protein (PLTP), which facilitates the transfer of phospholipids between lipoproteins and is able to remodel HDL [8-11]. PLTP and CETP may be involved in pre- $\beta$ HDL generation $[10,11]$.

Despite the increased cardiovascular risk in type 1 diabetes mellitus [12], current knowledge about alterations in RCT in this disease is limited. HDL cholesterol and plasma apo A-I levels are similar, or even higher, in adequately controlled uncomplicated type 1 diabetes [13-15]. Plasma PLTP activity is elevated in type 1 diabetic patients $[13,14]$. Considering the first step in RCT, some studies suggest that in-vitro glycation of HDL impairs its ability to promote cholesterol efflux out of human skin fibroblasts [16], but there are no data with respect to pre- $\beta$ HDL in type 1 diabetes mellitus.

HMG (hydroxymethylglutaryl) Co-A reductase inhibitors are well known to reduce LDL cholesterol as well as plasma triglyceride levels $[17,18]$, and to lower the incidence of cardiovascular disease [19-21]. Even with average cholesterol levels, statins have been proven to be beneficial [22], making it important to study the effects of statins in type 1 diabetes. Of interest, statin treatment may lower plasma cholesteryl ester transfer [23] and increase HDL cholesterol and plasma apo A-I [24]. No data are available concerning the effects of statin treatment on plasma pre- $\beta$ HDL and it is unknown whether this treatment affects the ability of plasma to promote cellular cholesterol efflux.

The aims of the present study were twofold. Firstly, we questioned whether the ability of plasma to generate pre- $\beta$ HDL and to promote cellular cholesterol efflux is altered in type 1 diabetic patients without microalbuminuria or clinically manifest cardiovascular disease. Secondly, we evaluated the effect of various doses of simvastatin on plasma HDL cholesterol, apo A-I, pre- $\beta$ HDL formation, plasma cholesterol esterification and cholesteryl ester transfer, and on the capacity of plasma to induce cellular cholesterol efflux in type 1 diabetic patients.

\section{Materials and methods}

The study was approved by the medical ethics committee of the University Medical Center Groningen, and all participants provided written informed consent. Fourteen male patients with type 1 diabetes mellitus (age $>18$ years) with an onset of disease before the age of 35 years and 13 agematched healthy men were studied. Type 1 diabetes mellitus patients were selected on having a fasting plasma total cholesterol level between 5.0 and $8.0 \mathrm{mmol} / \mathrm{l}$. Healthy subjects had fasting plasma total cholesterol levels $<6.0$ $\mathrm{mmol} / \mathrm{l}$. All participants had fasting plasma triglyceride $<2.5 \mathrm{mmol} / \mathrm{l}$. Only participants with a BMI $<30 \mathrm{~kg} / \mathrm{m}^{2}$ were included. In healthy subjects diabetes mellitus was excluded by a 75-g oral glucose tolerance test according to WHO criteria. Clinically manifest cardiovascular disease, alcohol use more than three drinks per day, urinary albumin excretion $>20 \mu \mathrm{g}$ per min, serum creatinine $>120 \mu \mathrm{mol} / 1$, hypertension (systolic/diastolic blood pressure $>140 / 90$ $\mathrm{mmHg}$ ), thyroid dysfunction and liver function abnormalities were exclusion criteria. Patients using medication other than insulin and antihypertensive drugs were excluded, as were subjects with transaminases $>1.5 \times$ above the upper reference limits.

Study design Type 1 diabetic patients and healthy subjects were compared while consuming their habitual diet. Six weeks before the intervention study, the type 1 diabetic patients were instructed to use a low-fat, low-cholesterol diet and to continue this diet throughout the study. In a crossover design they received simvastatin $10,20,40 \mathrm{mg}$ and placebo each during 6 weeks in random order in a double-blind fashion. At the end of each period blood was collected before the morning insulin injections.

Laboratory measurements Blood was collected after an overnight fast into EDTA-containing tubes $(1.5 \mathrm{mg} / \mathrm{ml})$ and placed on ice immediately. Plasma was obtained within $30 \mathrm{~min}$ by centrifugation at $1400 \mathrm{~g}$ for $15 \mathrm{~min}$ at $4^{\circ} \mathrm{C}$. Total cholesterol, triglyceride and choline-containing phospholipids were measured enzymatically as described [25]. HDL was separated in fresh plasma by precipitation of apo-B-containing lipoproteins using sodium phosphotungstate $/ \mathrm{MgCl}_{2}$. Very low density lipoprotein (VLDL)+LDL cholesterol was calculated as the difference between plasma total cholesterol and HDL cholesterol. LDL cholesterol was calculated by the Friedewald formula [26]. Apo A-I and $\mathrm{B}$ were assayed by immunoturbidimetry using kits from Serapak, Bayer, Leverkusen, Germany (cat. nos. 6821 and 6822, respectively). Plasma total cholesterol, triglyceride and HDL cholesterol were assayed shortly after blood collection. For further measurements, samples were kept frozen at $-80^{\circ} \mathrm{C}$ until analysis.

Plasma cholesteryl ester transfer was assayed essentially as described previously [25]. In brief, $\left[{ }^{3} \mathrm{H}\right]$ cholesterol was equilibrated for $24 \mathrm{~h}$ with plasma-free cholesterol at $4^{\circ} \mathrm{C}$ followed by incubation of the sample at $37^{\circ} \mathrm{C}$ for $3 \mathrm{~h}$. Subsequently, VLDL+LDL were precipitated by addition of phosphotungstate $/ \mathrm{MgCl}_{2}$. Lipids were extracted from the precipitate and the cholesteryl esters were isolated on silica columns and radioactivity was counted. Plasma cholesterol esterification was determined by measurement of formation of cholesteryl esters after addition of $\left[{ }^{3} \mathrm{H}\right]$ cholesterol to plasma. Equilibration of added $\left[{ }^{3} \mathrm{H}\right]$ cholesterol was obtained after incubation at $4^{\circ} \mathrm{C}$ for $24 \mathrm{~h}$. Subsequently, the plasma was incubated at $37^{\circ} \mathrm{C}$ for $1 \mathrm{~h} \mathrm{[25].}$ Plasma LCAT activity was measured using excess exogenous substrate containing $\left[{ }^{3} \mathrm{H}\right]$ cholesterol as described [27]. Plasma CETP activity levels were determined after precipitation of endogenous VLDL+LDL with sodium phosphotungstate $/ \mathrm{MgCl}_{2}$ [28]. The isotope assay measures the transfer of radioactive cholesteryl ester between excess exogenous $\left[1-{ }^{14} \mathrm{C}\right.$-oleate $]$-cholesteryl-ester-labelled LDL 
and an excess of pooled normal HDL, while LCAT is inhibited with dithiobis-2-nitrobenzoic acid. Plasma CETP activity was calculated as the bidirectional transfer between labelled LDL and HDL [29], and reflects the amount of active CETP in plasma. Plasma PLTP activity was assayed using a phospholipid-vesicles-HDL system, as previously described $[27,28]$. Small plasma samples $(1 \mu \mathrm{l})$ were incubated with $\left[{ }^{3} \mathrm{H}\right]$-phosphatidylcholine-labelled phosphatidylcholine vesicles and excess pooled normal HDL for $45 \mathrm{~min}$ at $37^{\circ} \mathrm{C}$. The vesicles were then precipitated using a mixture of $\mathrm{NaCl}, \mathrm{MgCl}_{2}$ and heparin (final concentrations: 230, $92 \mathrm{mmol} / \mathrm{l}$ and $200 \mathrm{IU} / \mathrm{ml}$, respectively). The PLTP activity levels vary linearly with the amount of plasma added to the incubation system. This method is specific for PLTP activity and the phospholipid transfer promoting properties of CETP do not interfere with the assay [28].

Plasma pre- $\beta$ HDL formation was measured as described [30], except that antihuman apo A-I and an incubation time of $24 \mathrm{~h}$ was used. In short, plasma samples were thawed while kept on ice and $0.9 \mu \mathrm{mol} / \mathrm{l}$ Pefabloc SC (Boehringer-Roche, Mannheim, Germany) and $1.8 \mu \mathrm{g} / 1$ Trasylol (Bayer, Leverkusen, Germany 10,000 IU/ml) were added to inhibit proteolysis (both final concentrations). Subsequently, an LCAT inhibitor was added (iodoacetate, final concentration $1.0 \mathrm{mmol} / \mathrm{l}$ ) and the samples were incubated at $37^{\circ} \mathrm{C}$ for $24 \mathrm{~h}$ to measure the formation of pre- $\beta$ HDL. The crossed immunoelectrophoresis consisted of agarose electrophoresis in the first dimension for separation of lipoproteins with pre- $\beta$ and $\alpha$ mobility. Antigen migration from the first agarose gel into the second agarose gel, containing goat antihuman apo A-I antiserum $(3 \%, v / v)$, was used to quantitatively precipitate apo A-I. The antiserum was monospecific for human apo A-I [31]. Lipoprotein electrophoresis was carried out in $1 \%(\mathrm{w} / \mathrm{v})$ agarose gels in barbital buffer $(50 \mathrm{mmol} / \mathrm{l}, \mathrm{pH} 8.6)$ and run in an LKB 2117 system $\left(4^{\circ} \mathrm{C}\right.$ for $\left.2 \mathrm{~h}, 250 \mathrm{~V}\right)$. Plasma was applied at $3 \mu \mathrm{l} / \mathrm{well}$. The track of the first agarose gel was excised and annealed with melted agarose to a gel containing 3\% (v/v) goat antihuman apo A-I anti-serum that was cast on GelBond film (Pharmacia, Uppsala, Sweden). The plate was run in an LKB 2117 system $\left(4^{\circ} \mathrm{C}\right.$ for $\left.20 \mathrm{~h}, 50 \mathrm{~V}\right)$ in barbital buffer. Unreacted antibody was removed by extensive washing in phosphate-buffered saline. The gel was stained with Coomassie brilliant blue R250 and subsequently dried. Areas under the pre- $\beta$ HDL and $\alpha$ HDL peaks were scanned and calculated using Scion software. The pre- $\beta$ HDL area was expressed as the percentage of the sum of the pre- $\beta$ HDL and the $\alpha$ HDL areas (percentage of total plasma apo A-I). Pre- $\beta$ HDL was also expressed in apo A-I concentration $(\mathrm{mg} / \mathrm{l})$.

Cholesterol efflux to plasma was determined using both Fu5AH cells (generous gift from Dr N. Fournier, ChatenayMalabry, France) and human fibroblasts as cholesterol donors. Fibroblasts were obtained from normolipidaemic control persons by explant culture from a $3-\mathrm{mm}$ punch biopsy at a $1 \mathrm{~mm}$ skin thickness and were cultured (until passage $5-15 \times$ ) in 24 -well culture plates to full confluency, essentially as described earlier [32]. Since efflux rates from fibroblasts and Fu5AH cells were compared with each other, both cell types were treated identically with respect to the efflux measurement procedure. The cells were cultured in DMEM supplemented with $10 \% \mathrm{v} / \mathrm{v}$ FCS. After washing them with DMEM, they were loaded with $\left[{ }^{3} \mathrm{H}\right]$ cholesterol (1406 Bq/mmol) during $24 \mathrm{~h}$ in the presence of added unlabelled cholesterol $(30 \mu \mathrm{g} / \mathrm{ml})$ in order to induce ABCA-1 in the fibroblasts. $\left[{ }^{3} \mathrm{H}\right]$ cholesterol and unlabelled cholesterol was solubilised in ethanol and diluted into the efflux medium. Subsequently, the cells were washed five times with PBS/BSA $0.2 \%(\mathrm{w} / \mathrm{v})$ and the efflux assay was started by adding plasma diluted to $1 \%$ in efflux medium. A plasma dilution of $1 \%$ was chosen because the apparent EC50 of efflux from fibroblasts is approximately $1 \%$. As previously reported [33], the apparent EC50 is higher for Fu5AH cells. Incubations were carried out in triplicate. After 4-h incubation at $37^{\circ} \mathrm{C}$ the medium was collected and centrifuged. Subsequently, $\left[{ }^{3} \mathrm{H}\right]$ cholesterol was quantified by liquid scintillation counting. Total cellular $\left[{ }^{3} \mathrm{H}\right]$ cholesterol was determined after extraction of the cells with 2-propanol. The percentage efflux was calculated by dividing the radioactive counts in the efflux medium by the sum of the counts in the medium and the cell extract. All values were corrected for radioactivity appearing in the culture medium in the absence of plasma. To be able to normalize results between series of experiments and to correct for day-to-day variation, efflux to $50 \mu \mathrm{g}$ protein/ ml HDL (Calbiochem, San Diego, CA, USA) was determined in triplicate. This HDL preparation was from one batch and was stored at $4^{\circ} \mathrm{C}$ following the instructions of the manufacturer.

To verify the effect of cholesterol loading on expression of ABCA1 protein in human cultured fibroblasts, a western blotting experiment was carried out. For this purpose fibroblasts were cultured with or without $30 \mu \mathrm{g} / \mathrm{ml}$ cholesterol as described above. Cells were harvested, centrifuged, and lysis buffer containing $25 \mathrm{mmol} / \mathrm{l}$ HEPES $\mathrm{pH}$ $7.5,5 \mathrm{mmol} / 1 \mathrm{MgCl}_{2}, 5 \mathrm{mmol} / \mathrm{l}$ EDTA, $2 \mathrm{mmol} / \mathrm{l}$ phenyl methyl sulphonylfluoride and complete protease inhibitor (Roche, Mijdrecht, The Netherlands) was added to the cell pellets. Cell lysates were obtained by freezing $\left(-80^{\circ} \mathrm{C}\right)$ and thawing $\left(37^{\circ} \mathrm{C}\right)$ the cell suspensions in four cycles. The protein concentrations in these lysates were determined by the BCA (Bicinchoninic Acid) assay [34]. Equal amounts of protein $(10 \mu \mathrm{g})$ were separated on a $6 \%$ SDSPAGE gel and electrophoretically transferred to nitrocellulose membrane (Schleicher \& Schuell, 's-Hertogenbosch, The Netherlands). Membrane was probed with a mouse monoclonal ABCA1 antibody (generous gift of $\mathrm{Dr} \mathrm{M}$ Hayden, UBC, Vancouver, BC, Canada) followed by immunoreactivity detection by lumilight western blotting substrate (Roche) (Fig. 1). As shown in Fig. 1, ABCA1 protein is present in cultured fibroblasts, and strongly induced after cholesterol loading.

Glycated haemoglobin $\left(\mathrm{HbA}_{1} \mathrm{c}\right)$ was measured by high performance liquid chromatography (Bio-Rad, Veenendaal, The Netherlands; normal range 4.6-6.1\%). 


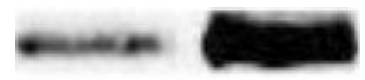

\section{Lane 1 Lane 2}

Fig. 1 ABCA1 protein levels in fibroblasts before and after cholesterol loading. Fibroblasts were incubated either without extra cholesterol or with $30 \mu \mathrm{g} / \mathrm{ml}$ cholesterol, exactly as described for the conditions where efflux was determined. Subsequently, fibroblasts were harvested and protein extracts were blotted as described in Materials and methods. Lane 1: no additions; lane 2: cholesterol loading

Statistical analysis Data are expressed as means \pm SD, unless stated otherwise. Baseline parameters in healthy subjects and type 1 diabetes mellitus patients were compared by unpaired Wilcoxon tests. Within-group changes in parameters after therapy with simvastatin and placebo were analysed by Friedman's two-way analysis of variance. Duncan's method was applied to correct for multiple comparisons. Bivariate correlations were evaluated by Spearman's rank correlation analysis. Because the participants were studied on four occasions, averaged correlation coefficients were computed by $Z$ transformation. A twosided $p$ value $<0.05$ was considered significant. Assuming an SD of cellular cholesterol efflux of $8 \%$ of the group mean [35] and a correlation coefficient between repeated measurements as low as 0.50 , it was calculated that a betweengroup difference of $9 \%$ and a change in cholesterol efflux of $7 \%$ could be demonstrated comparing 14 subjects per group and with 14 subjects in an intervention study, respectively, with a power of 0.85 and a two-sided $p$ value of 0.05 .

\section{Results}

Age and BMI were not different between type 1 diabetic patients and healthy subjects (Table 1). Disease duration was $26 \pm 15$ years and the patients used $51 \pm 19 \mathrm{IU}$ insulin/ day. Plasma total cholesterol $(p<0.001)$, VLDL+LDL cholesterol $(p<0.001)$, LDL cholesterol $(p<0.01)$ and apo B $(p<0.05)$ levels were higher in diabetic patients, whereas
Table 2 Plasma EST, CET, LCAT activity, CETP and PLTP activity in moderately hypercholesterolaemic type 1 diabetic patients and healthy normolipidaemic subjects

\begin{tabular}{lcl}
\hline & $\begin{array}{c}\text { Type 1 diabetic } \\
\text { patients }(n=14)\end{array}$ & $\begin{array}{l}\text { Healthy subjects } \\
(n=13)\end{array}$ \\
\hline EST $\left(\mathrm{nmol} \mathrm{ml}{ }^{-1} \mathrm{~h}^{-1}\right)$ & $101.2 \pm 21.5^{\mathrm{b}}$ & $59.6 \pm 18.7$ \\
CET $\left(\mathrm{nmol} \mathrm{ml} \mathrm{h}^{-1} \mathrm{~h}^{-1}\right)$ & $30.6 \pm 11.0^{\mathrm{a}}$ & $18.6 \pm 7.3$ \\
LCAT activity (AU) & $92.6 \pm 14.5$ & $82.7 \pm 15.6$ \\
CETP activity (AU) & $105.3 \pm 24.9^{\mathrm{a}}$ & $87.5 \pm 16.8$ \\
PLTP activity (AU) & $132.7 \pm 37.5^{\mathrm{b}}$ & $89.6 \pm 12.5$ \\
\hline
\end{tabular}

Data are given in means \pm SD

EST Cholesterol esterification, CET cholesteryl ester transfer, $L C A T$ lecithin:cholesterol acyl transferase, $C E T P$ cholesteryl ester transfer protein, $P L T P$ phospholipid transfer protein

${ }_{p}<0.05$ from healthy subjects

${ }^{\mathrm{b}} p<0.001$ from healthy subjects by unpaired Wilcoxon test

triglyceride levels were not different between patients and healthy subjects. HDL cholesterol was not significantly different between the two groups, but HDL phospholipids were higher in type 1 diabetic patients $(p<0.05)$. Plasma apo A-I was also higher in type 1 diabetic patients $(p<$ 0.05 ). Pre- $\beta$ HDL formation, expressed as percentage of total plasma apo A-I, as well as apo A-I concentration was not different in diabetic patients compared to healthy subjects $(n=12)$.

Plasma cholesterol esterification and cholesteryl ester transfer were elevated in type 1 diabetic patients (Table 2). Plasma CETP and PLTP activity levels were also higher in diabetic patients, whereas plasma LCAT activity was not different between the groups. As shown in Fig. 2, cholesterol efflux from Fu5AH cells to plasma from type 1 diabetic patients was higher $(9.1 \pm 1.3 \%$ per $4 \mathrm{~h}, p<0.001)$ compared to plasma from healthy subjects $(5.1 \pm 0.5 \%$ per $4 \mathrm{~h}$ ). Also with fibroblasts the ability of plasma to promote cholesterol efflux was higher with plasma from diabetic patients $(15.9 \pm 1.3 \%$ per $4 \mathrm{~h}, p<0.001)$ than with plasma from healthy subjects $(11.9 \pm 0.6 \%$ per $4 \mathrm{~h})$. The ratio of cholesterol efflux out of Fu5AH cells compared to efflux
Table 1 Clinical characteristics and plasma (apo)lipoprotein levels in moderately hypercholesterolaemic type 1 diabetic patients and healthy normolipidaemic subjects

Data are given in means \pm SD ${ }_{b}^{a}<0.05$ from healthy subjects ${ }_{p}^{\mathrm{b}}<0.01$ from healthy subjects ${ }^{c} p<0.001$ from healthy subject by unpaired Wilcoxon test

\begin{tabular}{lcc}
\hline & $\begin{array}{c}\text { Type 1 diabetic } \\
\text { patients }(n=14)\end{array}$ & $\begin{array}{c}\text { Healthy subjects } \\
(n=13)\end{array}$ \\
\hline Age (years) & $45 \pm 14$ & $51 \pm 8$ \\
Body mass index $\left(\mathrm{kg} / \mathrm{m}^{2}\right)$ & $25.9 \pm 3.0$ & $23.9 \pm 2.7$ \\
$\mathrm{HbA}_{1} \mathrm{c}(\%)$ & $7.8 \pm 1.3^{\mathrm{c}}$ & $5.1 \pm 0.24$ \\
Plasma total cholesterol $(\mathrm{mmol} / \mathrm{l})$ & $5.95 \pm 0.99^{\mathrm{c}}$ & $4.60 \pm 0.59$ \\
Plasma triglyceride $(\mathrm{mmol} / \mathrm{l})$ & $1.17 \pm 0.50$ & $1.02 \pm 0.58$ \\
VLDL+LDL cholesterol $(\mathrm{mmol} / \mathrm{l})$ & $4.89 \pm 1.01^{\mathrm{c}}$ & $3.60 \pm 0.69$ \\
LDL cholesterol $(\mathrm{mmol} / \mathrm{l})$ & $4.12 \pm 0.96^{\mathrm{b}}$ & $3.13 \pm 0.64$ \\
HDL phospholipids $(\mathrm{mmol} / \mathrm{l})$ & $1.29 \pm 0.23^{\mathrm{a}}$ & $1.08 \pm 0.23$ \\
HDL cholesterol $(\mathrm{mmol} / \mathrm{l})$ & $1.06 \pm 0.21$ & $1.01 \pm 0.29$ \\
Apolipoprotein A-I $(\mathrm{g} / \mathrm{l})$ & $1.38 \pm 0.14^{\mathrm{c}}$ & $1.15 \pm 0.17$ \\
Apolipoprotein B $(\mathrm{g} / \mathrm{l})$ & $1.04 \pm 0.20^{\mathrm{c}}$ & $0.76 \pm 0.12$ \\
Pre- $\beta$ HDL formation $($ apo A-I g/l) & $0.21 \pm 0.06$ & $0.18 \pm 0.06$ \\
Pre- $\beta$ HDL formation $(\%$ of total & $15.4 \pm 5.3$ & $16.1 \pm 4.7$ \\
plasma apo A-I) & & \\
\hline
\end{tabular}


a

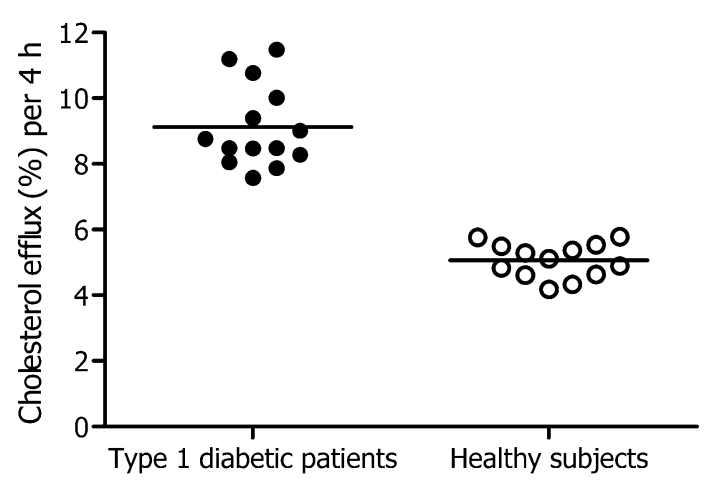

b

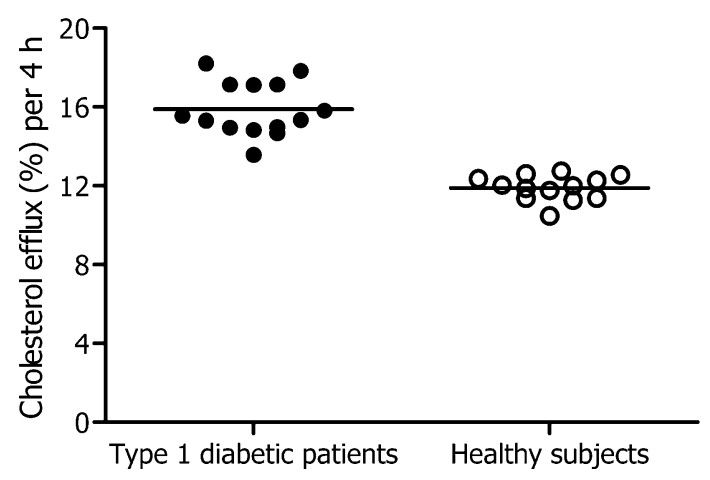

Fig. 2 Cholesterol efflux to plasma. a Efflux out of Fu5AH cells to plasma of moderately hypercholesterolaemic type 1 diabetic patients $(\bullet)$ and to plasma of healthy normolipidaemic subjects $(\circ, p<0.001)$. b Cholesterol efflux out of human skin fibroblasts to plasma of type 1 diabetic patients $(\bullet)$ and to plasma of healthy subjects $(\circ$, $p<0.001)$. Data were compared by unpaired Wilcoxon's test

out of fibroblasts was higher with diabetic plasma $(0.57 \pm$ $0.07, p<0.001)$ than with plasma from healthy subjects $(0.43 \pm 0.03)$. This indicates that cholesterol efflux from Fu5AH cells to diabetic plasma was increased more than efflux from fibroblasts. Among diabetic patients, there was no correlation between $\mathrm{HbA}_{1} \mathrm{c}$ and cholesterol efflux from Fu5AH cells $(r=0.32, \mathrm{NS})$ and fibroblasts $(r=0.24, \mathrm{NS})$.
There were no significant changes in any of the plasma (apo)lipoprotein variables, plasma LCAT, CETP, PLTP activities, cholesterol esterification and cholesteryl ester transfer obtained directly at the start of the study compared to the measurements during placebo administration (data not shown). Body weight and $\mathrm{HbA}_{1} \mathrm{c}$ remained unaltered during simvastatin treatment (Table 3). Simvastatin therapy decreased plasma total cholesterol, VLDL+LDL cholesterol, LDL cholesterol, triglyceride and apo B levels compared to placebo (all $p<0.05$; Table 3 ). The largest decreases in plasma total cholesterol, VLDL+LDL cholesterol, LDL cholesterol and apo B levels were seen in response to the highest simvastatin dose of $40 \mathrm{mg}$ daily. HDL cholesterol increased slightly but significantly during all simvastatin treatment periods $(p<0.05)$ without a doserelated effect. The increase in plasma apo A-I was significant after simvastatin $10 \mathrm{mg}(p<0.05)$. HDL phospholipids (Table 3 ) did not change significantly. Pre- $\beta$ HDL formation, both when expressed in apo A-I concentration and as a percentage of total plasma apo A-I, decreased in response to simvastatin treatment, but its change only reached significance after simvastatin $20 \mathrm{mg}$ daily $(p<0.05)$.

Plasma cholesterol esterification, cholesteryl ester transfer and CETP activity decreased after simvastatin treatment (all $p<0.05$; Table 4). No significant changes in plasma LCAT activity and PLTP activity were observed in response to simvastatin (Table 4). The ability of plasma to promote cholesterol efflux from Fu5AH cells and fibroblasts did not change significantly in response to simvastatin (Table 4).

The relative decreases in plasma cholesteryl ester transfer in response to the various doses of simvastatin were positively correlated with the relative decreases in VLDL+ LDL cholesterol (averaged $r=0.68, p<0.001$; Fig. 3a), plasma triglyceride (averaged $r=0.42, p=0.01$; Fig. 3b) and plasma CETP activity (averaged $r=0.52, p<0.001$; Fig. 3c). In turn, the relative changes in HDL cholesterol after treatment with simvastatin were correlated negatively with the relative changes in plasma cholesteryl ester transfer (averaged $r=-0.38, p<0.05$; Fig. $3 \mathrm{~d}$ ). The relative changes in pre- $\beta$ HDL formation were positively correlated with the
Table 3 Plasma lipid and lipoprotein levels in moderately hypercholesterolaemic type 1 diabetic mellitus patients $(n=14)$ after 6 weeks treatments with placebo, simvastatin 10,20 and $40 \mathrm{mg}$

\footnotetext{
Data are given in means $\pm \mathrm{SD}$ ${ }_{p} p 0.05$ from placebo ${ }^{\mathrm{b}} p<0.05$ from simvastatin $10 \mathrm{mg}$ by Friedman two-way analysis of variance
}

\begin{tabular}{lcccc}
\hline & Placebo & $\begin{array}{l}\text { Simvastatin } \\
(10 \mathrm{mg})\end{array}$ & $\begin{array}{c}\text { Simvastatin } \\
(20 \mathrm{mg})\end{array}$ & $\begin{array}{l}\text { Simvastatin } \\
(40 \mathrm{mg})\end{array}$ \\
\hline Weight (kg) & $83 \pm 14$ & $84 \pm 14$ & $83 \pm 13$ & $83 \pm 13$ \\
$\mathrm{HbA}_{1} \mathrm{c}(\%)$ & $7.8 \pm 1.5$ & $7.7 \pm 1.4$ & $7.8 \pm 1.1$ & $7.9 \pm 1.6$ \\
Plasma total cholesterol (mmol/l) & $5.47 \pm 0.85$ & $4.61 \pm 0.79$ & $4.24 \pm 0.68^{\mathrm{a}, \mathrm{b}}$ & $4.17 \pm 0.90^{\mathrm{a}, \mathrm{b}}$ \\
Plasma triglyceride (mmol/l) & $1.19 \pm 0.72$ & $1.02 \pm 0.58$ & $0.79 \pm 0.29^{\mathrm{a}, \mathrm{b}}$ & $0.92 \pm 0.47^{\mathrm{a}, \mathrm{b}}$ \\
VLDL+LDL cholesterol (mmol/1) & $4.50 \pm 0.93$ & $3.61 \pm 0.94^{\mathrm{a}}$ & $3.21 \pm 0.71^{\mathrm{a}, \mathrm{b}}$ & $3.15 \pm 1.00^{\mathrm{a}, \mathrm{b}}$ \\
LDL cholesterol (mmol/l) & $3.89 \pm 0.56$ & $3.04 \pm 0.62^{\mathrm{a}}$ & $2.81 \pm 0.58^{\mathrm{a}, \mathrm{b}}$ & $2.71 \pm 0.81^{\mathrm{a}, \mathrm{b}}$ \\
HDL phospholipids (mmol/1) & $1.26 \pm 0.22$ & $1.43 \pm 0.34$ & $1.31 \pm 0.31$ & $1.36 \pm 0.32$ \\
HDL cholesterol (mmol/1) & $0.97 \pm 0.17$ & $1.03 \pm 0.23^{\mathrm{a}}$ & $1.03 \pm 0.18^{\mathrm{a}}$ & $1.02 \pm 0.20^{\mathrm{a}}$ \\
Apolipoprotein A-I (g/l) & $1.19 \pm 0.18$ & $1.28 \pm 0.19^{\mathrm{a}}$ & $1.23 \pm 0.21$ & $1.24 \pm 0.22$ \\
Apolipoprotein B (g/l) & $0.93 \pm 0.18$ & $0.79 \pm 0.21^{\mathrm{a}}$ & $0.72 \pm 0.18^{\mathrm{a}}$ & $0.71 \pm 0.22^{\mathrm{a}}$ \\
Pre- $\beta$ HDL formation (apo A-I g/l) & $0.15 \pm 0.06$ & $0.14 \pm 0.06$ & $0.11 \pm 0.06^{\mathrm{a}}$ & $0.13 \pm 0.06$ \\
Pre- $\beta$ HDL (\% of total plasma apo A-I) & $10.3 \pm 0.3$ & $8.4 \pm 4.7$ & $7.0 \pm 4.3^{\mathrm{a}}$ & $8.0 \pm 4.1$ \\
\hline
\end{tabular}


Table 4 EST rate, CET, LCAT activity, CETP activity, PLTP activity and cholesterol efflux from Fu5AH cells and fibroblasts in type 1 diabetic patients $(n=14)$ after 6 weeks treatments with placebo, simvastatin 10, 20 and $40 \mathrm{mg}$

\begin{tabular}{|c|c|c|c|c|}
\hline & Placebo & $\begin{array}{l}\text { Simvastatin } \\
(10 \mathrm{mg})\end{array}$ & $\begin{array}{l}\text { Simvastatin } \\
(20 \mathrm{mg})\end{array}$ & $\begin{array}{l}\text { Simvastatin } \\
(40 \mathrm{mg})\end{array}$ \\
\hline $\operatorname{EST}\left(\mathrm{nmol} \mathrm{m} \mathrm{m}^{-1} \mathrm{~h}^{-1}\right)$ & $101.4 \pm 31.3$ & $96.8 \pm 31.4$ & $87.8 \pm 22.8^{\mathrm{a}}$ & $88.4 \pm 25.5^{\mathrm{a}}$ \\
\hline LCAT activity (AU) & $90.9 \pm 18.9$ & $87.1 \pm 15.4$ & $85.8 \pm 16.3$ & $87.3 \pm 14.9$ \\
\hline CETP activity (AU) & $94.5 \pm 23.7$ & $88.7 \pm 24.0^{\mathrm{a}}$ & $84.1 \pm 14.6^{\mathrm{a}}$ & $83.7 \pm 18.1^{\mathrm{a}}$ \\
\hline PLTP activity (AU) & $124.2 \pm 33.6$ & $125.8 \pm 26.6$ & $119.9 \pm 27.9$ & $120.0 \pm 30.1$ \\
\hline Cholesterol efflux fibroblasts $(\% / 4 \mathrm{~h})$ & $15.6 \pm 1.4$ & $15.4 \pm 1.6$ & $15.7 \pm 1.2$ & $15.1 \pm 1.4$ \\
\hline
\end{tabular}

Data are given in means \pm SD

EST Cholesterol esterification, CET cholesteryl ester transfer, LCAT lecithin:cholesterol acyl transferase, CETP cholesteryl ester transfer protein, PLTP phospholipid transfer protein ${ }_{p} p<0.05$ from placebo

${ }^{\mathrm{b}} p<0.05$ from simvastatin $10 \mathrm{mg}$ by Friedman two-way analysis of variance

relative changes in plasma triglyceride (for pre- $\beta$ HDL formation expressed as percentage of total plasma apo A-I: averaged $r=0.46, p<0.01$; for pre- $\beta$ HDL formation expressed in apo A-I concentrations: averaged $r=0.42, p<0.01$ ) and negatively with the relative changes in HDL cholesterol (for pre- $\beta$ HDL formation expressed as percentage of total plasma apo A-I: averaged $r=-0.36, p<0.05$; pre- $\beta$ HDL formation expressed in apo A-I concentrations: averaged $r=-0.28$, NS; data not shown).
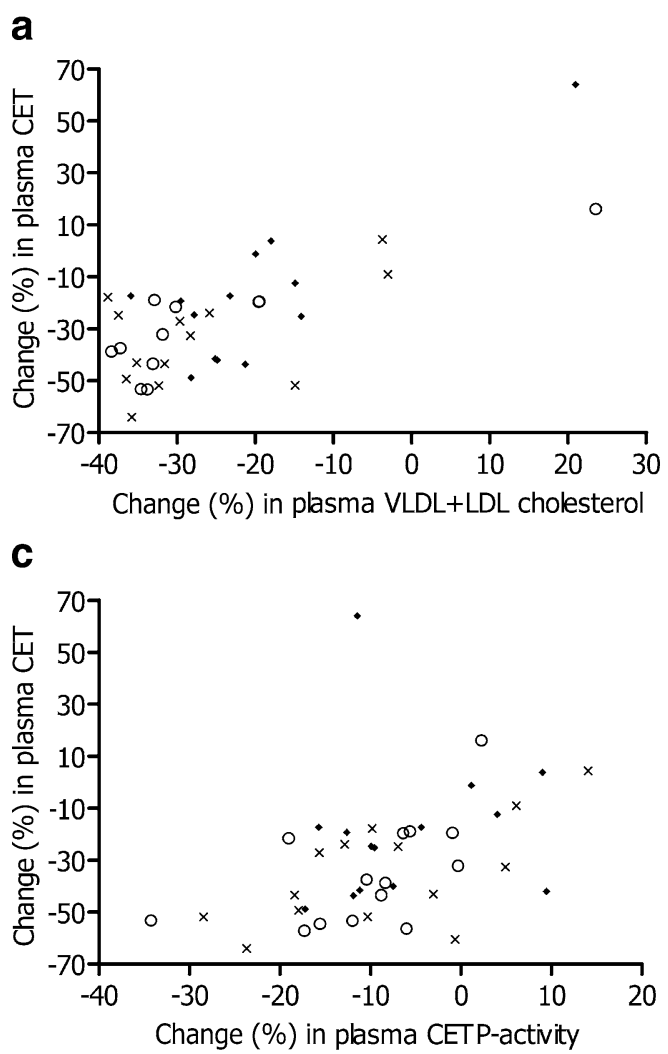

Fig. 3 Relationships of changes, in response to various doses of simvastatin, in plasma cholesteryl ester transfer (CET) with a changes in VLDL+LDL cholesterol (averaged $r=0.68, p<0.001$ ), b plasma triglyceride (averaged $r=0.42, p=0.01$ ), and $\mathbf{c}$ plasma cholesteryl ester

\section{Discussion}

This study demonstrates for the first time that the capacity of plasma from moderately hypercholesterolaemic type 1 diabetic patients to promote cholesterol efflux out of both Fu5AH rat hepatoma cells and human skin fibroblasts is elevated compared to healthy subjects. Plasma apo A-I, HDL phospholipids and plasma PLTP activity, but not HDL cholesterol and pre- $\beta$ HDL formation, were elevated

b

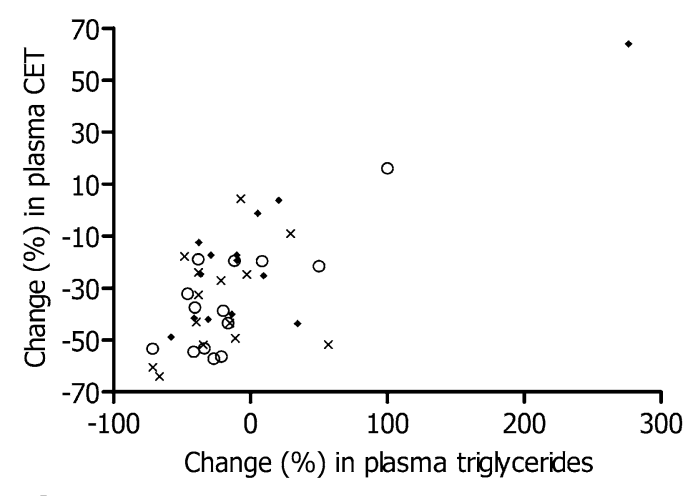

d

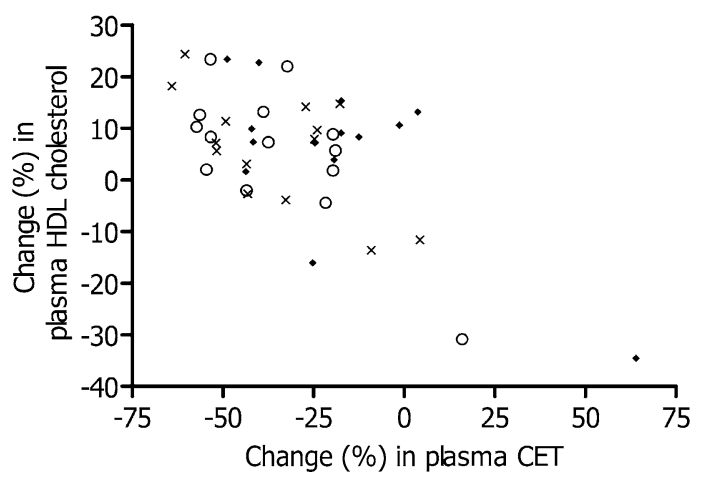

transfer protein (CETP) activity (averaged $r=0.52, p<0.001$ ). d Relationships of changes in HDL cholesterol with changes in plasma CET (averaged $r=-0.38, p<0.05$ ). $\bullet$, simvastatin $10 \mathrm{mg} ; \times$, simvastatin $20 \mathrm{mg}$; $\circ$, simvastatin $40 \mathrm{mg}$ 
in these type 1 diabetic patients without microalbuminuria and cardiovascular disease. Secondly, simvastatin administration lowered VLDL+LDL cholesterol, LDL cholesterol and plasma triglyceride as well as plasma CETP activity, cholesteryl ester transfer and cholesterol esterification; but this treatment did not affect plasma LCAT activity and PLTP activity. HDL cholesterol was modestly increased, but pre- $\beta$ HDL formation tended to decrease in response to treatment with this $\mathrm{HMG} \mathrm{Co}-\mathrm{A}$ reductase inhibitor. Importantly, no alterations in the ability of plasma to promote cellular cholesterol efflux were seen after simvastatin treatment, neither with Fu5AH cells nor with human fibroblasts.

Plasma PLTP activity is elevated in type 1 diabetes [13, $14]$ and this increase in PLTP activity is associated with the presence of more large HDL, less small HDL and more plasma apo A-I and apo A-II $[13,14]$. Our findings with respect to plasma PLTP activity and plasma apo A-I correspond to these studies. High plasma PLTP activity will enhance the transfer of phospholipids from triglyceriderich lipoproteins to HDL, contributing to higher HDL phospholipids in type 1 diabetes. It has not been reported previously that pre- $\beta$ HDL formation is unaltered in type 1 diabetes mellitus. Pre- $\beta$ HDL generation by PLTP in vitro is enhanced by enrichment of HDL with triglyceride [36]; therefore, it appears that an elevated plasma PLTP activity does not result in increased pre- $\beta$ HDL formation under normotriglyceridaemic circumstances as found in type 1 diabetes mellitus. Plasma CETP activity, assayed by a method that measures the amount of active CETP, is unaltered in normoalbuminuric type 1 diabetic patients [15] and slightly elevated when patients with albuminuria are included in the comparison with healthy subjects [13]. Despite this elevated plasma CETP activity, plasma cholesteryl ester transfer is lower, particularly in male type 1 diabetic patients, due to lower plasma triglyceride and LDL cholesterol [13], indicating the importance of apo-B-containing acceptor lipoproteins in plasma cholesteryl ester transfer [37]. Because plasma CETP activity is higher in hypercholesterolaemia [38], the elevated plasma CETP activity in the currently studied type 1 diabetic patients is most likely related to their higher plasma cholesterol levels. Moreover, the higher plasma cholesteryl ester transfer and, probably also cholesterol esterification, might be explained by higher concentrations of plasma cholesteryl ester acceptor lipoproteins in these patients.

Cellular cholesterol efflux to extracellular acceptors is a complex process, in which several mechanisms participate, including aqueous diffusion, scavenger receptor class B type I (SR-BI)- and ATP-binding cassette transporter A1 (ABCA1)-mediated efflux [39, 40]. In the present study, we used rat hepatoma Fu5AH cells, which express SR-BI abundantly but hardly any ABCA1, as well as cultured human skin fibroblasts, which express little CLA-1, the human analogue of SR-BI [39, 41]. The relevance of ABCA1 for cholesterol efflux out of human cultured fibroblasts is underscored by the observation that cholesterol efflux to purified apo A1 is almost abrogated with fibroblasts from Tangier patients [32]. It has been previously shown that ABCA1 mRNA expression is induced in fibroblasts by cholesterol preloading [42]. In our study it was demonstrated that $\mathrm{ABCA} 1$ protein is strongly induced under the present conditions of cholesterol loading. Therefore, it is likely that ABCA1 contributes to a considerable extent to cholesterol efflux out of cultured fibroblasts to plasma, but the exact importance of ABCA1-mediated cholesterol efflux compared to other processes involved is still unclear. In this regard it could be relevant that ABCG1 and ABCG4 transporters have been very recently shown to stimulate cellular cholesterol efflux to mature HDL [43]. The possible role of these transporters, in the enhanced ability of diabetic plasma to promote cholesterol efflux from Fu5AH cells or fibroblasts, deserves further study.

Cholesterol efflux out of Fu5AH cells via SR-BI is largely dependent on mature HDL, and is correlated positively with HDL cholesterol, HDL phospholipids and plasma apo A-I [33, 39, 44], whereas lipid-poor acceptors, including pre- $\beta$ HDL, are important in ABCA1-dependent cholesterol efflux [45]. The relatively higher stimulatory effect of diabetic plasma on cholesterol efflux out of Fu5AH cells, compared to fibroblasts, suggests that plasma from type 1 diabetic patients predominantly enhances SRBI-mediated efflux. The higher concentration of HDL phospholipids, which could be due to higher plasma PLTP activity, may, in part, explain this effect. Furthermore, higher PLTP activity levels may be responsible for enhanced cholesterol efflux from fibroblasts to diabetic plasma, because PLTP directly stimulates cholesterol removal from human fibroblasts [46]. It is unlikely that the elevated cholesterol efflux to diabetic plasma, at least with respect to Fu5AH cells, is affected by selection of patients with moderate hypercholesterolaemia, because cholesterol efflux from these cells is not determined by plasma LDL cholesterol and apo B levels, or by the rate of plasma cholesterol esterification and cholesteryl ester transfer [33]. It is relevant in this respect that in-vitro glycation of HDLassociated apolipoproteins may impair cell-derived cholesterol removal [16, 47], although this has not always been observed [48]. The enhanced cellular cholesterol efflux to diabetic plasma that was found here suggests that in-vivo apolipoprotein glycation does not impair this process considerably, provided metabolic control is acceptable.

LDL-cholesterol lowering, in response to the HMG CoA reductase inhibitor, atorvastatin, is accompanied by a decrease in plasma CETP activity and in cholesteryl ester transfer in hypertriglyceridaemic [49] and in combined hyperlipidaemic subjects $[50,51]$. This effect on plasma cholesteryl ester transfer is also seen in normolipidaemic subjects treated with simvastatin [23]. In the present study, the decrease in plasma cholesteryl ester transfer found during simvastatin treatment was correlated with the decrease in VLDL+LDL cholesterol and plasma triglyceride, as well as with the drop in plasma CETP activity, suggesting that the decrease in cholesteryl-ester acceptor lipoproteins and in plasma CETP activity as such is important in the inhibition of cholesteryl ester transfer after statin 
treatment. Moreover, the modest rise in HDL cholesterol was correlated with the decrease in plasma cholesteryl ester transfer. Thus, our study shows that the decrease in cholesteryl-ester-acceptor lipoproteins, combined with the drop in plasma CETP activity, provides a mechanism to explain the increase in HDL cholesterol in response to statin treatment. Notably, pre- $\beta$ HDL formation tended to decrease after simvastatin treatment, and these changes were correlated positively with the changes in plasma triglyceride and negatively with the changes in HDL cholesterol. Taken together, the present data suggest that statin treatment induces a shift towards more mature HDL particles, as was found in type 2 diabetic patients with ischaemic heart disease [52].

The ability of plasma to promote cholesterol efflux from either Fu5AH cells or human skin fibroblasts did not change during treatment with simvastatin, despite an increase in HDL cholesterol. Thus, alterations in the constellation of HDL particles elicited by simvastatin treatment do not result in an improvement of RCT in type 1 diabetes mellitus, as far the potential of plasma to stimulate cellderived cholesterol removal is concerned. Comparison of the only data available so far, demonstrates that cholesterol efflux from Fu5AH cells to plasma from type IIB hyperlipidaemic subjects is increased after atorvastatin treatment in association with a pronounced rise in HDL cholesterol and plasma apo A-I [51]. It is unknown whether this difference is due to the patient category studied, the magnitude of the rise in HDL cholesterol and plasma apo A-I after statin treatment or to other factors.

Our study does not allow a final conclusion with respect to possible alterations in the in-situ capacity of peripheral cells involved in RCT to transport cholesterol to the extracellular compartment, since we documented the capacity of plasma to promote cholesterol efflux out of in-vitro cell systems. Abnormalities in properties of vascular cells in the diabetic environment, for example concerning SR-BI interaction with extracellular cholesterol acceptors or $A B$ $C A 1$ gene expression [8], as well as pleiotropic actions of statins on vascular tissue [53], could also exert important effects on RCT. Furthermore, HDL has other atheroprotective properties, besides RCT [54], which were not evaluated in the present study.

In conclusion, this study shows that the ability of plasma from moderately hypercholesterolaemic type 1 diabetic patients to stimulate cholesterol efflux out of cultured Fu5AH cells and human skin fibroblasts is enhanced. Thus, as far as the constellation of extracellular cholesterol acceptors is concerned, this early step in RCT is not impaired in type 1 diabetic patients with acceptable metabolic control. Furthermore, simvastatin increases HDL cholesterol via lowering of plasma cholesteryl ester transfer. The simvastatin-induced changes in HDL do not result in a further increase in cellular cholesterol efflux.
Acknowledgements R. de Vries is supported by a grant from the Dutch Diabetes Foundation (grant 2001.00.012). R. Buirma, Merck Sharp \& Dohme, The Netherlands, provided simvastatin and placebo medication. The laboratory measurements of this study were financially supported by Merck Sharpe \& Dohme, The Netherlands. The expert technical assistance of H. Elias, T. van Gent, L.M. Scheek and Dr E. E. Blaauwwiekel is highly appreciated. B.J. Beusekamp provided dietary advice.

\section{References}

1. Tall AR (1990) Plasma high density lipoproteins. Metabolism and relationship to atherogenesis. J Clin Invest 86:379-384

2. Fielding CJ, Fielding PE (1995) Molecular physiology of reverse cholesterol transport. J Lipid Res 36:211-228

3. Barter PJ, Rye KA (1993) High density lipoproteins and reverse cholesterol transport. Curr Opin Lipidol 4:210-217

4. Bruce C, Tall AR (1995) Cholesteryl ester transfer proteins, reverse cholesterol transport, and atherosclerosis. Curr Opin Lipidol 6:311

5. Eisenberg S (1984) High density lipoprotein metabolism. J Lipid Res 25:1017-1058

6. Castro GR, Fielding CJ (1988) Early incorporation of cellderived cholesterol into pre- $\beta$-migrating high-density lipoprotein. Biochemistry 27:25-29

7. Von Eckardstein A, Huang Y, Assmann G (1994) Physiological role and clinical relevance of high-density lipoprotein subclasses. Curr Opin Lipidol 5:404-416

8. Borggreve SE, De Vries R, Dullaart RPF (2003) Alterations in high-density lipoprotein metabolism and reverse cholesterol transport in insulin resistance and type 2 diabetes mellitus: role of lipolytic enzymes, lecithin:cholesterol acyltransferase and lipid transfer proteins. Eur J Clin Invest 33:1051-1069

9. Jauhiainen M, Metso J, Pahlman R, Blomqvist S, Van Tol A, Ehnholm C (1993) Human plasma phospholipid transfer protein causes high density lipoprotein conversion. J Biol Chem 268: 4032-4036

10. Von Eckardstein A, Jauhiainen M, Huang Y et al (1996) Phospholipid transfer protein mediated conversion of high density lipoproteins generates pre $\beta 1$-HDL. Biochim Biophys Acta 1301:255-262

11. Rye KA, Clay MA, Barter PJ (1999) Remodelling of high density lipoproteins by plasma factors. Atherosclerosis 145: 227-238

12. Krolewski AS, Kosinski EJ, Warram JH et al (1987) Magnitude and determinants of coronary artery disease in juvenile-onset, insulin-dependent diabetes mellitus. Am J Cardiol 59:750-755

13. Colhoun HM, Scheek LM, Rubens MB et al (2001) Lipid transfer protein activities in type 1 diabetic patients without renal failure and nondiabetic control subjects and their association with coronary artery calcification. Diabetes 50:652-659

14. Colhoun HM, Taskinen MR, Otvos JD, Van Den Berg P, O'Connor J, Van Tol A (2002) Relationship of phospholipid transfer protein activity to HDL and apolipoprotein B-containing lipoproteins in subjects with and without type 1 diabetes. Diabetes 51:3300-3305

15. Dullaart RPF (1995) Plasma lipoprotein abnormalities in type 1 (insulin-dependent) diabetes mellitus. Neth J Med 46:44-54

16. Duell PB, Oram JF, Bierman EL (1991) Nonenzymatic glycosylation of HDL and impaired HDL-receptor-mediated cholesterol efflux. Diabetes 40:377-384

17. Jones P, Kafonek S, Laurora I, Hunninghake D (1998) Comparative dose efficacy study of atorvastatin versus simvastatin, pravastatin, lovastatin en fluvastatin in patients with hypercholesteremia (the CURVES study). Am J Cardiol 81:582-587 
18. Rustemeijer C, Schouten JA, Janssens ENW, Spooren PFMJ, Van Doormaal JJ (1997) Pravastatin in diabetes-associated hypercholesterolemia. Acta Diabetol 34:294-300

19. Herd JA, Ballantyne CM, Farmer JA et al (1997) Effects of fluvastatine on coronary atherosclerosis in patients with mild to moderate cholesterol elevations (Lipoprotein and Coronary Atherosclerosis Study [LCAS]). Am J Cardiol 80:278-286

20. 4S Study Group (1994) Randomised trial of cholesterol lowering in 4444 patients with coronary heart disease: the Scandinavian Simvastatin Survival Study (4S). Lancet 344:1383-1389

21. Plehn JF, Davis BR, Sacks FM et al (1999) Reduction of stroke incidence after myocardial infarction with pravastatin: the Cholesterol and Recurrent Events (CARE) study. The Care investigators. Circulation 99:216-223

22. Downs LR, Clearfield M, Weis S et al (1998) Primary prevention of acute coronary events with lovastatin in men and women with average cholesterol levels: results of AFCAPS/TexCAPS. Air Force/Texas coronary atherosclerosis prevention study. JAMA 279:1615-1622

23. Ahnadi CE, Berthezène F, Ponsin G (1993) Simvastatin-induced decrease in the transfer of cholesterol esters from high density lipoproteins to very low and low density lipoproteins in normolipidemic subjects. Atherosclerosis 99:219-228

24. Schaefer JR, Schweer H, Ikewaki K et al (1999) Metabolic basis of high density lipoproteins and apolipoprotein A-I increase by HMG-CoA reductase inhibition in healthy subjects and a patient with coronary artery disease. Atherosclerosis 144:177-184

25. Dullaart RPF, Riemens SC, Scheek LM, Van Tol A (1999) Insulin decreases plasma cholesteryl ester transport but not cholesterol esterification in healthy subjects as well as in normotriglyceridemic patients type 2 diabetes. Eur J Clin Invest 29: 663-671

26. Friedewald WT, Levy RI, Fredrickson DS (1972) Estimation of the concentration of low-density lipoprotein cholesterol in plasma without use of the preparative ultracentrifuge. Clin Chem 18:499-552

27. Dullaart RPF, Sluiter WJ, Dikkeschei LD, Hoogenberg K, Van Tol A (1994) Effect of adiposity on plasma lipid transfer protein activities: a possible link between insulin resistance and high density lipoprotein metabolism. Eur J Clin Invest 24:188-194

28. Speijer H, Groener JE, Van Ramshorst E, Van Tol A (1991) Different locations of cholesteryl ester transfer protein and phospholipid transfer protein activities in plasma. Atherosclerosis 90:159-168

29. Groener JE, Pelton RW, Kostner GM (1986) Improved estimation of cholesteryl ester transfer/exchange activity in serum or plasma. Clin Chem 32:283-286

30. Van Haperen R, Van Tol A, Vermeulen P et al (2000) Human plasma phospholipid transfer protein increases the antiatherogenic potential of high density lipoproteins in transgenic mice. Arterioscler Thromb Vasc Biol 20:1082-1088

31. Brussaard JH, Dallinga-Thie GM, Groot PHE, Katan MB (1980) Effects of amount and type of dietary fat on serum lipids, lipoproteins and apolipoproteins in man. A controlled 8-week trial. Atherosclerosis 36:515-527

32. Hovingh GK, Wijland MJ, Brownlie A et al (2003) The role of the ABCA1 transporter and cholesterol efflux in familial hypoalphalipoproteinemia. J Lipid Res 44:1251-1255

33. De La Llera-Moya M, Atger V, Paul JL et al (1994) A cell culture system for screening human serum for ability to promote cellular cholesterol efflux. Relations between serum components and efflux, esterification, and transfer. Arterioscler Thromb 14: 1056-1065

34. Smith PK, Krohn RI, Hermanson GT et al (1985) Measurement of protein using bicinchoninic acid. Ann Biochem 150:76-85

35. Dullaart RPF, Van Tol A (2001) Twenty four hour insulin infusion impairs the ability of plasma from healthy subjects and type 2 diabetic patients to promote cellular cholesterol efflux. Atherosclerosis 157:49-56

36. Rye KA, Jensen G, Barter PJ, Ehnholm C (1998) Triglycerideenrichment of high density lipoproteins enhances their remodelling by phospholipid transfer protein. J Lipid Res 39:613-622
37. Mann CJ, Yen FT, Grant AM, Bihain BE (1991) Mechanism of plasma cholesteryl ester transfer in hypertriglyceridemia. J Clin Invest 88:2059-2066

38. Tato F, Vega F, Tall AR, Grundy SM (1995) Relation between cholesterol transfer protein activities and lipoprotein cholesterol in patients with hypercholesterolemia and combined hyperlipidemia. Arterioscler Thromb Vasc Biol 15:112-120

39. Rothblat GH, De La Llera-Moya M, Atger V, Kellner-Weibel G, Williams DL, Phillips MC (1999) Cell cholesterol efflux: integration of old and new observations provides new insights. J Lipid Res 40:781-796

40. Yancey PG, Bortnick AE, Kellner-Weibel G, De La Llera-Moya M, Phillips MC, Rothblat GH (2003) Importance of different pathways of cellular cholesterol efflux. Arterioscler Thromb Vasc Biol 23:712-719

41. Fielding CJ, Bist A, Fielding PE (1999) Intracellular cholesterol transport in synchronized human skin fibroblasts. Biochemistry 38:2506-2513

42. Denis M, Bissonnette R, Haidar B, Krimbou L, Bouvier M, Genest J (2003) Expression, regulation, and activity of ABCA1 in human cell lines. Mol Genet Metab 78:265-274

43. Wang N, Lan D, Chen W, Matsuura F, Tall AR (2004) ATPbinding cassette transporters G1 and G4 mediate cellular cholesterol efflux to high-density lipoproteins. Proc Natl Acad Sci U S A 101:9774-9779

44. Fournier N, Paul JL, Atger V et al (1997) HDL phospholipid content and composition as a major factor determining cholesterol efflux capacity from Fu5AH cells to human serum. Arterioscler Thromb Vasc Biol 17:2685-2691

45. Favari E, Lee M, Calabresi L, Franceschini G, Zimetti F, Kovanen PT (2004) Depletion of pre-beta-high density lipoprotein by human chymase impairs ATP-binding cassette transporter A1-but not scavenger receptor class B type I-mediated lipid efflux to high density lipoprotein. J Biol Chem 279:9930 9936

46. Oram J, Wolfbauer G, Vecchio G, Albers JJ (2003) Phospholipid transfer protein interacts with and stabilizes ATP-binding cassette transporter A1 and enhances cholesterol efflux from cells. J Biol Chem 26:52379-52385

47. Igau B, Castro G, Clavey V et al (1997) In vivo glycosylated LpA-I subfraction. Evidence for structural and functional alterations. Arterioscler Thromb Vasc Biol 17:2830-2836

48. Passarelli M, Shimabukuro AFM, Catanozi S et al (2000) Diminished rate of mouse peritoneal macrophage cholesterol efflux is not related to the degree of HDL glycation in diabetes mellitus. Clin Chim Acta 301:119-134

49. Le NA, Innis-Whitehouse W, Li X, Bakker-Arkema R, Black D, Brown WV (2000) Lipid and apolipoprotein levels and distribution in patients with hypertriglyceridemia: effect of triglyceride reductions with atorvastatin. Metabolism 49:167-177

50. Guérin M, Lassel TS, Le Goff W, Farnier M, Chapman MJ (2000) Action of atorvastatin in combined hyperlipidemia. Preferential reduction of cholesteryl ester transfer from HDL to VLDL1 particles. Arterioscler Thromb Vasc Biol 20:189-197

51. Guérin M, Egger P, Soudant C et al (2002) Dose-dependent action of atorvastatin in type IIB hyperlipidemia: preferential and progressive reduction of atherogenic apoB-containing lipoprotein subclasses (VLDL-2, IDL, small dense LDL) and stimulation of cellular cholesterol efflux. Atherosclerosis 163: 287-296

52. Soedamah-Muthu SS, Colhoun HM, Thomason MJ et al (2003) The effects of atorvastatin on serum lipids, lipoproteins and NMR spectroscopy defined lipoprotein subclasses in type 2 diabetic patients with ischaemic heart disease. Atherosclerosis 167:243-255

53. Wolfrum S, Jensen KS, Liao JK (2003) Endothelium-dependent effects of statins. Arterioscler Thromb Vasc Biol 23:729-736

54. Nofer JR, Kehrel B, Fobker M, Levkau B, Assmann G, Von Eckardstein A (2002) HDL and arteriosclerosis: beyond reverse cholesterol transport. Atherosclerosis 161:1-16 